\title{
Exacerbated signs of an immunosuppressive AIDS-like disease in macaques infected with multiple retroviruses
}

\author{
Jane L Mitchell', Simon Hood', Ghazi Auda², Neil M Almond', Nicola J Rose ${ }^{1 *}$ \\ From 15th International Conference on Human Retroviruses: HTLV and Related Viruses \\ Leuven and Gembloux, Belgium. 5-8 June 2011
}

In retroviral co-infection one or more of the viruses may display altered dynamics impacting on the pathology within the host. To characterise the nature of such changes we studied cynomolgus macaques naturally infected with three retroviruses. DNA was isolated from eleven tissues from macaques infected with SFV-1 (4), SRV-2/SFV-1 (4), STLV-1/SFV-1 (3), SRV-2/STLV-1/ SFV-1 (6), and one uninfected macaque. Proviral load and distribution were evaluated by quantitative PCR. Immunopathology was assessed by H\&E staining and immunohistochemistry, using antibodies against T-, B-lymphocytes and macrophages in the MLN and spleen.

Our data reveal that in co-infected macaques a significant increase in the SRV-2 proviral distribution and a trend towards an increase in the proviral load of SRV-2 but not STLV-I or SFV-1 occurs Pathological changes were more adverse in co-infected macaques, identified by the presence of nodular hyperplasia or, in extreme instances, follicular depletion. A greater number of B- and $\mathrm{T}$-lymphocytes and macrophages were observed in coinfected macaques than in singly-infected macaques. The atypical distribution of the B- and T-cells is suggestive of altered immunopathology. Thus co-infection increases the distribution and proviral load of SRV-2 thereby creating an atypical immunopathology within the lymphoid organs which may enhance SRV-2 pathogenesis and hinder the host's ability to control infection.

\section{Author details}

${ }^{1}$ Division of Retrovirology, National Institute for Biological Standards and Control, South Mimms, Potters Bar, Hertford, EN6 3QG, UK. ${ }^{2}$ Division of

\footnotetext{
* Correspondence: nicola.rose@nibsc.hpa.org.uk

'Division of Retrovirology, National Institute for Biological Standards and

Control, South Mimms, Potters Bar, Hertford, EN6 3QG, UK

Full list of author information is available at the end of the article
}

Virology, National Institute for Biological Standards and Control, South Mimms, Potters Bar, Hertford, EN6 3QG, UK.

Published: 6 June 2011

doi:10.1186/1742-4690-8-S1-A207

Cite this article as: Mitchell et al.: Exacerbated signs of an

immunosuppressive AIDS-like disease in macaques infected with multiple retroviruses. Retrovirology 2011 8(Suppl 1):A207.
Submit your next manuscript to BioMed Central and take full advantage of:

- Convenient online submission

- Thorough peer review

- No space constraints or color figure charges

- Immediate publication on acceptance

- Inclusion in PubMed, CAS, Scopus and Google Scholar

- Research which is freely available for redistribution

\section{() Biomed Central}

